УДК 78:37.01

DOI:

Михайло Сидор, кандидат мистеитвознавства, доиент кафедри культурології та мистецької освіти Дрогобицького державного педагогічного університету імені Івана Франка

\title{
ПІЗНАВАЛЬНИЙ, РОЗВИВАЛЬНИЙ І ВИХОВНИЙ АСПЕКТИ НАРОДНОГО МИСТЕЦТВА ЯК СКЛАДОВІ МОДЕРУВАННЯ СУЧАСНОЇ МИСТЕЦЬКОЇ ОСВІТИ
}

Розкриваються сутнісний та функиіональний контексти народного мистеитва через аналіз його пізнавальних, розвивальних і виховних потенцій, їх місия і ролі у формуванні ерудованої, компетентної, різнобічно розвиненої особистості, здатної вливатися у сучасний соичум, відповідати його запитам, інтересам та нормам життя. Ставлячи предмет дослідження в ранг актуальних компонент модерування сучасної мистецької освіти, автор доводить, щуо рухаючись вперед, надаючи перевагу інноваційному, глобалізованому у моделюванні змісту життя, не варто нехтувати здобутками минулого, його традиціями i звичаями, оскільки без них теперішнє і майбутнє втрачає свій повноцінний сенс.

Ключові слова: народне мистецтво; сутність; функиї; мистецька освіта; сучасність; освітній процес; модерування.

תim. 11.

Mykhaylo Sydor, Ph.D.(Study of Art), Associate Professor of the Cultural Studies and Art Education Department Ivan Franko Drohobych State Pedagogical University

\section{INFORMATIVE, DEVELOPING AND EDUCATIONALASPECTS OF FOLKART AS A COMPONENT OF MODERATION OF MODERN ART EDUCATION}

The leading line of materials presented in the article is vectorized to reveal and substantiate the coexistence and synthesis of modern and traditional, innovative and enduring, integrated and substantive as actual, conceptual and inalienable concepts in the discourse on the globalization processes taking place in the present world, in particular on the concepts of transition of all mankind to a fundamentally new post-industrial civilization in general and the planetary society in particular.

In the specified way, under a particular angle of view and aspects of scientific vision, the essential and functional contexts of folk art as a special field of cultural and creative progress of Ukrainians are highlighted. Through the prism of the analysis of its cognitive, developmental and educational potentials, their place and role in the field of the formation of erudite, competent, versatile personality capable of penetrating into the modern society, to meet its demands, interests and norms of the present dynamic life is determined. Putting the subject of research into the rank of actual and effective components of moderation of modern artistic education, the author argues that moving forward, opening the new, giving preference to a modern, innovative, globalized modelling of the content and forms of the present life, should not neglect the achievements of the past, the traditions generated by him and customs of material, spiritual, general cultural nature, since without them the present and future loses its meaningful meaning. In the justification, the above emphasis is placed on the fact that the development of students as young generations, on the true bases of domestic art, must necessarily include the study of "folk" branch. It is about understanding of one's national background, knowledge of the origins, ways of development and general features of artistic creation of folk artists, penetration of the principles of perception of the world, ideas and concepts of artistic expression of the real and the imaginary. All this is so significant that without that, even the simplest algorithm for the acquisition of artistic education will be destroyed and the process of learning, upbringing and development in this area will become unproductive. It follows that these vectors and the content of artistic and aesthetic education, based on the idea of the revival of national culture, artistic traditions, achievements, are indisputably popular, relevant and extremely important and significant both for the younger generations in particular and for society as a whole.

Keywords: folk art; essence; functions; artistic education; modernity; an educational process; moderation.

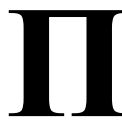
остановка проблеми. Глобалізаційні процеси, що відбуваються у теперішньому світі, вимагають переходу людства до принципово нової постіндустріальної цивілізації загалом та планерного суспільства зокрема. При цьому йдеться про культуро-соціальні орієнтири не як “залишки” минулого, що регулюють та коректують наше теперішне, а як принципово нове, співзвучне постіндустріальній епосі, що сутнісно відрізняється від нинішньої індустріальної $[4,44]$. Означене $\epsilon$ важливим для планування різних 


\section{ПІЗНАВАЛЬНИЙ, РОЗВИВАЛЬНИЙ І ВИХОВНИЙ АСПЕКТИНАРОДНОГО МИСТЕЦТВА ЯК СКЛАДОВІ МОДЕРУВАННЯ СУЧАСНОЇ МИСТЕЦЬКОЇ ОСВІТИ}

галузей життя. Окрім того, ним вибудовуються алгоритми реальних змін у сферах світосприйняття, розуміння місця і ролі людини в укладі світу, природи, формування ціннісних пріоритетів і т. ін.

Не оминули означені тенденції і царини освіти. 3 настанням нового тисячоліття одним з головних аспектів соціальної політики сучасної держави постало реформування освіти, безпосередньо спрямоване на усунення невідповідності чинної системи освіти об'єктивним вимогам сучасної епохи, засадам підготовки людини до продуктивного входження у соціум [5, 147].

Торкаючись безпосередньо галузі мистецької освіти, піддаючи їі об'єктивному аналізу, змістовній професійній оцінці, неодмінно бачимо, що сьогодні вже не можна задовольнятися лише моноаспектним вивченням того чи того виду мистецтва. Доречним у цьому плані виступає інтегрований підхід до навчання, актуалізований теперішніми тенденціями як світової педагогічної системи, так і традиціями української освіти зокрема. Роль останньої спричинена чинниками iі модерування, серед яких, зокрема: пропагування національного, виховання в дусі національного, збереження і пошанування національних надбань. Без цієї платформи націєтворення набуті знання, уміння й навички зазвичай виступають обмеженими, неповними, оскільки відірвані від істинного начала формування не лише предметно, а й різнобічно компетентної особистості, здатної успішно вирішувати життєві завдання та відповідати запитам суспільства.

Аналіз досліджень і публікацій. Звернення до означеної проблеми через безпосереднє вивчення іiї наукового визначення і обгрунтування, аналіз змістів напрацьованого відповідними фахівцями дає підгрунтя констатувати, що піднімані питання не $є$ сьогодні чимось таким, що можна класифікувати як “непізнане”, “неосягнуте" чи в цілому “незвідане". Зі здобуттям нашою країною незалежності актуалізувалися, а від так розширилися у різних напрямах та набули вагомих результатів відповідні наукові дослідження. Наприклад, у сфері розкриття суті мистецтва, його змістів, функцій значимими є наукові доробки С. Антоновича, О. Голубця, В. Жишковича, Я. Запаска, Р. ЗахарчукЧугай, М. Моздира, О. Никорак, В. Овсійчука, М. Селівачова, В. Сидоренка, М. Станкевича, Г. Стельмащук, І. Туманова, Н. Урсу, О. Федорука, Л. Хом'як, О. Чуйка, Р. Яціва та ін. У з'ясуванні передумов і засад розвитку мистецької освіти, висвітленні її реалій, зв'язків із цариною загальної освіти вагомим внеском постають праці
Н. Авер'янової, С. Волкова, Л. Любарської, І. Ляшенка, Л. Масол, С. Нікуленко, О. Овчарук, М. Резніченка, О. Рудницької, Л. Савицької, Л. Соколюк, Р. Шмагала та ін. У дослідженні методології мистецько-освітньої проблематики, ролі мистецтва та мистецької освіти у формуванні духовного потенціалу людини значимими є роботи I. Зязюна, О. Олексюк, В. Орлова, Г. Падалки, О. Рудницької, Л. Сліпчишин, О. Щолокової. Висвітленню проблем гуманізації особистості, становлення й розвитку її світоглядної позиції засобами пластичних мистецтв, естетичного виховання присвячені напрацювання В. Бітаєва, Л. Левчук, В. Мазепи, О. Оніщенко, С. Уланової, В. Чернеця. Розв'язанням тих же проблем через призму національного виховання характеризуються роботи А. Алексюка, О. Вишневського, В. Каюкова, П. Кононенка, I. Мартинюка, А. Погрібного, М. Стельмаховича, Є. Сявавко та ін. Проте, зважаючи на динаміку розвитку вітчизняної освіти, зокрема їі мистецької гілки, різноаспектність відповідних їй змін, реальних вдосконалень, реформ буквально на всіх ділянках цієї галузі, розширення ареалу затребуваності соціальними інституціями та перехід на інтегрованість з іншими сферами діяльності людини, неодмінно актуалізуються питання щодо уточнення змістових контекстів сучасної мистецької освіти 3 усіма їх корективами і доповненнями, відповідності реальному часу та перспективам на майбутнє. Серед усього цього в поле нашого професійного інтересу потрапила проблема, яка безпосередньо виражена як предмет розгляду у цій праці - пізнавальний, розвивальний і виховний аспекти народного мистецтва як важливі складові модерування сучасної мистецької освіти.

Мета статті - проаналізувати ключові аспекти дієвості народного мистецтва як освітньо-виховного компонента, визначити їх місце і роль у процесах модерування сучасної мистецької освіти.

Виклад основного матеріалу. Ні для кого не $є$ таємницею, що навчання - це складний, багатогранний, трудомісткий процес. Його ключові завдання передусім скеровані на вироблення та постійне вдосконалення в учня/ студента вмінь самостійно вчитися, віднаходити сприятливі шляхи і засоби для максимально повного засвоєння навчального матеріалу. Не менш значимим $є$ й набуття здатності творчо і креативно мислити, приймати нестандартні рішення у нестандартних ситуаціях. Цей перелік повниться й формуванням основи для вільного світоглядного самовизначення кожного як інтелектуально-креативної, добре обізнаної й 


\section{ПІЗНАВАЛЬНИЙ, РОЗВИВАЛЬНИЙ І ВИХОВНИЙ АСПЕКТИ НАРОДНОГОМИСТЕЦТВА ЯК СКЛАДОВІ МОДЕРУВАННЯ СУЧАСНОЇ МИСТЕЦЬКОЇ ОСВІТИ}

неодмінно творчої особистості [4, 44], яка здатна удосконалювати сучасність та будувати майбутнє на засадах знань, креативу, творчості, досконалості, професіоналізму і т. ін.

Вибудовуючи на окресленому розумінні лінію матеріалів цієї статті, ми провели змістовний аналіз низки відповідних джерел та реального стану сучасної вітчизняної мистецької освіти. Результат реально опрацьованого дає підстави ствердити, що новітні тенденції модерування цієї освітньої сфери характеризуються проникненням інтеграційних процесів на всі їі рівні та ешелони. Ідея загальноєвропейської інтеграції в галузі освіти, і зокрема мистецької, втілюється у їі стандартизації, що базується на компетентнісному підході. Як результат цієї характерної компоненти, інтеграція різних ступенів освіти в часових координатах породжує такі явища, як неперервна освіта, навчання впродовж усього життя. Відтак зміцнення міждисциплінарних зв'язків між предметами художньо-естетичного спрямування спричиняє їх об'єднання в межах нової освітньої галузі - мистецької освіти $[2,4]$.

Варто відзначити й те, що концепція розвитку мистецької освіти третього тисячоліття характеризується набуттям інтеркультурного виміру [7, 540]. Закономірність такого зумовлена загостренням міжнаціональних суперечностей, тому інтеркультурне виховання стає не просто вагомою, а й вкрай необхідною компонентою загальної педагогіки. Окрім того, важливість інтеркультурної компетентності підростаючих поколінь зумовлюється потребою їх виховання в дусі поваги до інших культур, розширення їхніх потенційних когнітивних можливостей, формування у кожній особистості готовності до міжкультурного діалогу, до врегулювання міжнаціональних і етнічних конфліктів шляхом переговорів і пошуку консенсусу $[2,5]$.

Іноді формат окресленого призводить до дискусій з приводу того, що ж все-таки має бути первинним, визначальним і базовим в освітніх процесах - моделювання, освоєння та пропагування інноваційного, інтеграційного, глобального, міжнародного, чи пізнання, збереження й популяризація традиційного, усталеного, вивіреного часом та вподобаннями рідного народу. Звісно, позитивне вирішення цієї проблеми в дусі сучасних концепцій укладів людського життя зумовлює дивитися вперед, прагнути до нового, інтегрованого, глобального. Однак, це аж ніяк не має відводити, а по суті й не відводить на задній план пізнання національного підгрунтя розвитку мистецтва, засад і концептів виховання мистця чи загалом особистості в дусі національних ідей, збереження і пропагування традицій рідного народу. Бо добре відомою є та істина, що завдання художньо-естетичної освіти, які тим чи тим сенсом спираються на ідею відродження своєї національної культури, є не просто затребуваними, а й вкрай важливими i значимими як для підростаючих поколінь, так і для суспільства в цілому $[8,113]$. Отож, маємо підстави ствердно зауважити, що формування художнього світогляду будь-якої особистості починаючи від раннього дитячого віку і до зрілої людини - неможливе без належного вивчення та усвідомлення ії генетичного коріння, пізнання та пошанування історії рідного народу, його культурних традицій, звичаїв, художніх смаків, уподобань і т. ін. $[11,46]$.

Означене зростає кратно, коли говоримо про професійну художню підготовку, введення у світ того чи того різновиду народного мистецтва не лише на засадах пропедевтики, а, власне, через призму здобуття певної мистецької професії, фахового вивчення відповідних художніх базисів, критеріїв, концепцій, технічно-технологічних аспектів, які виформовувалися й відшліфовувалися в народній творчості віками. Таке передусім зумовлене національною парадигмою підготовки фахівців 3 образотворчого та декоративноприкладного мистецтва як діалектикою особливого і загального в культурі, яка неодмінно забезпечує повноцінну соціалізацію майбутніх фахівців, грунтовне засвоєння ними як національної, так і загальнолюдської культури. Разом $з$ тим, означеним передбачається й формування та розвиток ціннісних орієнтацій у сфері опанування національної культури, а також застосування в освітньому процесі на рівні художнього пізнання народної творчості, властивих їй поступів, проявів і т. ін. $[6,16]$.

Розглядаючи викладене вище через актуальні механізми набуття мистецької освіти, пізнання природи народного мистецтва, змісту і форм його сучасного входження в соціум, неодмінно торкнемося найактуальніших концептуальних положень. Передусім зробимо акцент на тому, що їхня дієвість охоплює весь ареал педагогічної діяльності в галузі художнього навчання і виховання, у тому числі й виховання в аспектах національного. Введення у світ мистецтва загалом та різні види народної творчості зокрема передбачає визначення провідних ідей, напрямів та змістів знань щодо засад їх художнього навчання, розвитку і виховання, з'ясування провідних позицій та аспектів, навколо яких зосереджуються всі інші структурні компоненти мистецького педагогічного середовища. У 


\section{ППЗНАВАЛЬНИЙ, РОЗВИВАЛЬНИЙ І ВИХОВНИЙ АСПЕКТИНАРОДНОГОМИСТЕЦТВА ЯКСКЛАДОВІ МОДЕРУВАННЯ СУЧАСНОӤ МИСТЕЦЬКОЇОСВІТИ}

сказаному робимо конкретну заувагу, що методологічні орієнтири, які впливають на вибір продуктивних педагогічних стратегій у галузі сучасної образотворчої освіти, включають, насамперед, орієнтацію на гуманістичні підходи. Це вимагає рухатися за векторами, серед яких зсув пріоритетів 3 матеріальних цінностей на духовні, з однобічного спрямування на масові підходи - на увагу до кожної особистості, до внутрішнього світу кожної окремої людини $[3,126]$.

Актуалізуючи напрацьоване, хочемо знову зауважити, що серед чинних методологічних засад загальної мистецької педагогіки особливого звучання набуває саме національна основа мистецького навчання. Означене зумовлене тим, що національна культура повсякчас виступає одним з основних джерел становлення митця. Прагнення об'єктивно охопити мистецьку дійсність без твердої опори на національну художню основу містить у собі небезпеку поверховості в сприйманні й творенні художніх образів, відсутності усієї широти й повноти поглядів на засади і принципи життя, збідненості засобів художньої виразності, зведення їх до “бутафорної” сутності $[9,43]$.

Концепти мистецького навчання на національній основі, на засадах пошанування народних традицій, мистецьких звичаїв, смаків, уподобань вимагають цілеспрямованого системного збагачення освітнього процесу 3 відповідних мистецьких дисциплін художніми творами й артефактами національної художньої культури. Означене доповнюємо й послідовним системним стимулюванням реципієнтів до істинного пізнання й глибокого усвідомлення національної основи художніх творів, емпатійноемоційного ставлення до національної сутності художніх образів $[1,54]$. Сюди додаємо й проведення в освітньому процесі чітких художніх паралелей між творами в різних видах мистецтва за національно-стильовими ознаками; залучення підростаючих поколінь до усвідомленого відтворення національних ознак мистецтва у власній художній творчості $[10,35]$.

Методологічне обгрунтування продуктивного мистецького навчання, вивчення народної творчості, засобів і форм її предметного втілення включає й системність поєднання різних шляхів і прийомів освоєння того чи того виду мистецтва, виявом якої $\epsilon$ єдність раціональних та ірраціональних, об'єктивних і суб'єктивних способів пізнання мистецтва.

Значимими у модеруванні мистецької освіти $€$ принципи пізнання мистецтва. Суть таких розглядаємо як базові положення, що охоплюють узагальнені закономірності мистецької освіти, органічно пов'язуючи всі її окремі елементи в єдине ціле, пронизане духом національного, народного, традиційного й, водночас, сучасного та новітнього. Серед ключових бачимо: принцип культуровідповідності, як наповнення освітнього процесу, в результаті якого мистецтво, форми його прояву сприймаються як важлива культурна цінність, як надбання розвитку культури рідного народу, етнічних спільнот, населення певного регіону, а відтак світової культури загалом; принцип естетичної спрямованості, програмований на спонукання у процесі мистецького навчання до осягнення естетичної цінності художніх творів, до сприймання мистецтва як явища, що неодмінно містить потенціал втілення прекрасного в житті; принцип цілісності, як забезпечення спрямованості змісту, всіх форм і методів навчальної діяльності на єдину провідну мету особистісно-художній розвиток; принцип рефлективності, спрямований на спонукання здобувача мистецької освіти до співвіднесення власних життєвих орієнтирів зі змістом художніх образів, зіставлення цінностей життя з моральносвітоглядними позиціями, відтвореними в мистецтві; принцип індивідуалізації, як піклування про виявлення й збереження здатності до своєрідного, притаманного сприймання мистецтва, оцінювання його творів, розвиток спроможності до вибору й застосування унікальних, характерних для конкретного індивіду засобів мистецької творчості.

Не менш важливим $є$ й питання забезпечення педагогічних умов навчання мистецтва. У цьому плані вони мають виступати як цілеспрямовано створені обставини, дотримання яких сприяє ефективності художнього розвитку особистості. Сучасні теорія і методика навчання мистецтва надають перевагу таким педагогічним умовам і форматам, які здатні створити сприятливу атмосферу для здобуття освіти, досягнути повноцінної взаємодії між педагогом і учнем/ студентом, забезпечити пріоритетність продуктивної й неодмінно творчої діяльності $[1,55]$.

Висновки. Підсумовуючи викладене вище, перший акцент ставимо на тому, що світ, у якому живе теперішнє суспільство, насправді дуже складний і різноманітний. Для нього характерні різні форми людської діяльності, способи, технології і механізми їх провадження, безпосередня матеріалізація ідей і задумів. Однак, усі можливі діапазони прояву людського буття не виформовуються самі по собі, не з'являються ні звідки і не функціонують без 


\section{ПІЗНАВАЛЬНИЙ, РОЗВИВАЛЬНИЙ І ВИХОВНИЙ АСПЕКТИ НАРОДНОГОМИСТЕЦТВА ЯКСКЛАДОВІ МОДЕРУВАННЯ СУЧАСНОӤ МИСТЕЦЬКОЇ ОСВІТИ}

належних для них засад i умов. Тому результативність освітніх процесів у межах досліджуваної проблеми напряму залежить від змісту і якості надання освіти, від того, чого і як навчається їі здобувач.

Наступний акцент ставимо на злагодженості та взаємоузгодженні викладеного вище. Ці моменти розглядаємо ключовими критеріями, які уможливлюють модерувати повноцінний освітній процес в рамках пізнання народного мистецтва через призму не лише художнього, а й національного виховання. Посередництвом такого учні, студенти ознайомлюватимуться 3 усіма доступними й посильними їм у навчанні сферами народної художньої творчості, скеровуватимуться на пізнання їх особливостей, механізмів виконання творів на засадах традицій, новаторств та їхнього синтезу. Нехтуючи хоча б одним компонентом цієї “системи”, яка уможливлює досягнення високих успіхів в освоєнні народного мистецтва за принципом “навчаючи народній творчості виховуємо в дусі національного, етнічного, рідного", провокуємо розлад в довершеності відповідної ланки освіти та загалом знецінення виховання підростаючих поколінь.

Дотримуючись означених орієнтирів та настанов, важливо пам'ятати і про наповнення освітнього процесу істинним національним етикетом, що грунтується на базових цінностях українських традицій. Такі безпосередньо визначають, що все наше оточення, предмети i речі навколо нас, природа, соціум, у яких ми існуємо і які реально формуємо, зумовлюють наше особливе ставлення до них, створюють певну усталену духовну атмосферу, панування національного духу. Звідси випливає, що хоч би яких сучасних художніх методів чи стильових напрямів дотримувався митець, істинна сила його таланту, глибина художнього пізнання навколишнього світу прямо й безпосередньо залежать від національного коріння як художнього дару, так і тих творчих здібностей, які розвиваються на його платформі.

\section{ЛІТЕРАТУРА}

1. Агейкіна-Старченко Т. Інтерактивні методи розвитку професійної компетентності вчителів мистецьких дисциплін. Відкритий урок: розробки, технологіï, досвід. 2010. № 10. С. 53-55.

2. Актуальні питання мистецької освіти та виховання: збірник наук. праць: вип. 1 (1) / Гол. ред. Г. Ю. Ніколаї. Суми: СумДПУ імені А. С. Макаренка, 2013.214 с.

3. Бех І. Д. Духовні цінності в розвитку особистості. Педагогіка і психологія. 1997. № 1. С. 124-129.

4. Діденко Л. В., Кондрашова-Діденко В.І. Інтелектокреативні перетворення у виш. освіті: виклики майбутнього і відповіді сучасності. Вісник Київського національного університету імені Тараса Шевченка. 2012. Вип. 28. С. 44-46.

5. Огієнко О. І. Скандинавський досвід підготовки педагогів для системи освіти дорослих. Вісник Глухівського державного педагогічного університету. 2008. Вип. 12. С. 147-152.

6. Падалка Г. М. Педагогіка мистецтва (теорія і методика викладання мистецьких дисциплін). Київ, 2008. $274 \mathrm{c}$.

7. Сирота 3. М., Сирота В. М. Розвиток творчих здібностей і універсалізм образного світосприймання. Професійна мистеиька освіта і художня культура: виклики XXI cm. Матеріали Міжнар. наук.-практ. конф. (Київ, 16-17 жовтня 2014 р.). Київ, 2014. С. 538 543.

8. Сідлецька Т. І. Становлення і розвиток мистецької освіти в Україні. Знання. Освіта. Освіченість. $3 б$. матеріалів I Міжснар. наук.-практ. конф. (Вінниця, 2527 вересня 2012 р.). Вінниця, 2012. С. 112-115.

9. Сопільник М. Національно-стильові особливості культур у становленні майстра декоративноужиткового мистецтва. Рідна школа. 2003. № 9. С. 4143.

10. Фічора I. Народне декоративно-прикладне мистецтво в естетичному вихованні учнів. Рідна школа. 1999. № 7-8. С. 34-36.

11. Щолокова О. П. Концептуальні засади сучасної мистецько-педагогічної освіти в Україні. Мистецька освіта у вимірах сучасності: проблеми теорії та практики. Київ, 2014. С. 23-47.

\section{REFERENCES}

1. Aheikina-Starchenko, T. (2010). Interaktyvni metody rozvytku profesiinoi kompetentnosti vchyteliv mystetskykh dystsyplin [Interactive methods for the development of professional competence of teachers of artistic disciplines]. Open lesson: development, technology, experience. No. 10, pp. 53-55. [in Ukrainian].

2. Aktualni pytannia mystetskoi osvity ta vykhovannia: zbirnyk nauk. prats (2013). [Topical issues of artistic education and education: a collection of scientific works]. Vol. 1 (1). Sumy: SumDPU imeni A. S. Makarenka, 214 p. [in Ukrainian].

3. Bekh, I. D. (1997). Dukhovni tsinnosti v rozvytku osobystosti [Spiritual values in the development of personality]. Pedagogy and psychology. No. 1, pp. 124 129. [in Ukrainian].

4. Didenko, L. V. \& Kondrashova-Didenko, V. I. (2012). Intelekto-kreatyvni peretvorennia u vysh-osviti: vyklyky maibutnoho i vidpovidi suchasnosti [Intellect-creative transformations in higher education: the challenges of the future and the answers of the present]. Bulletin of the Taras Shevchenko National University of Kyiv. Vol. 28, pp. 44-46. [in Ukrainian].

5. Ohiienko, O. I. (2008). Skandynavskyi dosvid pidhotovky pedahohiv dlia systemy osvity doroslykh [Scandinavian experience of training teachers for adult education]. Bulletin of the Glukhiv State Pedagogical University. Vol. 12, pp. 147-152. [in Ukrainian]. 


\section{ОСОБЛИВОСТІПРОФЕСІЙНО-ОРІЕНТОВАНОГО НАВЧАННЯ ІНОЗЕМНОЇ МОВИ СТУДЕНТІВ НЕМОВНИХСПЕЦАЛЬНОСТЕЙ}

6. Padalka, H. M. (2008). Pedahohika mystetstva (teoriia i metodyka vykladannia mystetskykh dystsyplin) [Pedagogy of art (theory and methodology of teaching artistic disciplines)]. Kyiv, 274 p. [in Ukrainian].

7. Syrota, Z. M. \& Syrota, V. M. (2014). Rozvytok tvorchykh zdibnostei i universalizm obraznoho svitospryimannia [Development of creative abilities and universalism of figurative world perception]. Professional artistic education and artistic culture: Challenges of the XXI century. Materials of the International Scientific and Practical Conference (Kyiv, October 16-17, 2014). Kyiv, pp. 538-543. [in Ukrainian].

8. Sidletska, T. I. (2012). Stanovlennia i rozvytok mystetskoi osvity v Ukraini [Formation and development of artistic education in Ukraine]. Knowledge. Education. Education. Collection of materials of the I International
Scientific and Practical Conference. (Vinnitsa, 25, September 27, 2012). Vinnytsia, pp. 112-115. [in Ukrainian].

9. Sopilnyk, M. (2003). Natsionalno-stylovi osoblyvosti kultur u stanovlenni maistra dekoratyvnouzhytkovoho mystetstva [National-style features of cultures in becoming master of decorative and applied arts]. Native school. No. 9, pp. 41-43. [in Ukrainian].

10. Fichora, I. (1999). Narodne dekoratyvno-prykladne mystetstvo v estetychnomu vykhovanni uchniv [Folk arts and crafts in the aesthetic education of students]. Native school. No. 7-8, pp. 34-36. [in Ukrainian].

11. Shcholokova, O. P.(2014).Kontseptualni zasady suchasnoi mystetsko-pedahohichnoi osvity v Ukraini [Conceptual foundations of modern artistic and pedagogical education in Ukraine]. Artistic education in the dimensions of the present: problems of theory and practice. Kyiv, pp. 23-47. [in Ukrainian].

Стаття надійшла до редакції 04.07.2019

УДК 378:81.243

DOI:

Уляна Кецик-Зінченко, кандидат педагогічних наук, доцент кафедри іноземних мов Прикарпатського національного університету імені Василя Стефаника

\section{ОСОБЛИВОСТІ ПРОФЕСІЙНО-ОРІЕНТОВАНОГО НАВЧАННЯ ІНОЗЕМНОӤ МОВИ СТУДЕНТІВ НЕМОВНИХ СПЕЦІАЛЬНОСТЕЙ}

У статті розкрито сутність поняття професійно-орієнтованого навчання іноземної мови, визначено мету навчання іноземної мови на немовних факультетах ЗВО. Розглядаються деякі критерї відбору лексикограматичного матеріалу для професійно-орієнтованого навчання іноземної мови студентів немовних спечіальностей. Звертається увага на необхідність диферениійованого підходу до пошуку і добору навчального матеріалу з метою використання його у процесі професійної комунікації. Автор розкриває роль автентичних іншомовних фахових текстів у формуванні професійної іншомовної комунікативноі компетентності у майбутніх фахівиів.

Ключові слова: професійно-орієнтоване навчання; іноземна мова; професійна іншомовна комунікативна компетениія; немовні спечіальності.

Jim. 6.

Ulyana Ketsyk-Zinchenko, Ph.D.(Pedagogy), Associate Professor of the Foreign Languages Department Precarpathian Vasyl Stefanyk National University

\section{FEATURES OF PROFESSION-ORIENTED FOREIGN LANGUAGE TEACHING FOR STUDENTS OF NON-LINGUISTIC FACULTIES}

The article deals with the features of profession-oriented foreign language teaching for students at nonlinguistic faculties of higher educational establishments. The essence of the concept of professionally-oriented teaching foreign languages is revealed, the goal of teaching a foreign language at non-linguistic faculties of higher educational institutions is determined. The author states that studying foreign languages at non-linguistic faculties at higher educational institutions is professionally directed. This means that the languages are taught in order to teach students to apply them in their professional activities - to read special foreign-language literature for obtaining the necessary information, as well as be able to communicate with foreign colleagues on professional issues.

Along with this, the teaching a foreign language to future specialists should be considered through the prism of their further professional activities. Some criteria of selecting terminological vocabularies (glossaries) for developing students' communicative skills and habits in the process of profession-oriented teaching foreign languages have been considered. The author reveals the role of authentic professional texts in forming professional foreign speech competence in prospective specialists. She has drawn the reader's attention to the necessity of differentiated approach in choosing authentic reading materials with the aim further application in profession-oriented foreign language teaching.

Students are most interested when the educational material is based on the chosen specialty that stimulates 